\title{
HUBUNGAN KEBERSIHAN DAPUR DAN KONSTRUKSI RUMAH DENGAN KEBERADAAN TIKUS DI RUMAH WARGA DUSUN MAJAPAHIT KELURAHAN KALIERANG KECAMATAN BUMIAYU KABUPATEN BREBES TAHUN 2018
}

\author{
Devi Widya Arianti 1), Djamaluddin Ramlan 2), Budi Utomo ${ }^{3)}$ \\ Jurusan Kesehatan Lingkungan, Politeknik Kesehatan Kemenkes Semarang \\ Jl. Raya Baturaden KM. 12 Purwokerto, Indonesia
}

\begin{abstract}
Abstrak
Perumahan merupakan peranan penting bagi manusia yang berfungsi sebagai tempat tinggal untuk memenuhi kebutuhan dasar manusia dan juga merupakan determinan kesehatan masyarakat. Jenis penelitian ini adalah observasional dengan pendekatan cross sectional. Metode yang digunakan yaitu observasi dan wawancara secara langsung pada responden. Analisis data menggunakan analisis tabel, yaitu dianalisis secara deskriptif. Hasil penelitian dari 86 unit rumah diketahui ada 52 rumah (60.5\%) keadaan dapurnya bersih, ada 34 unit rumah (39.5\%) keadaan dapurnya kotor, ada 38 unit rumah (44.2\%) konstruksi rumahnya rapat tikus, ada 48 unit rumah (33.7\%) konstruksi rumahnya tidak rapat tikus. Kesimpulan Uji statistik menggunakan uji chi-square diperoleh nilai sig sebesar 0.00 sehingga sig<0.05 ada hubungan kebersihan dapur dan konstruksi rumah dengan keberadaan tikus. Saran sebaiknya selalu membersihkan dapur dari sisa makanan/ bahan makanan maupun kotoran lainnya yang tercecer, konstruksi rumah yang belum rapat tikus untuk dibuat konstruksi rumah yang rapat tikus.
\end{abstract}

Kata Kunci: Kebersihan Dapur, Konstruksi Rumah, Tikus

\begin{abstract}
[The Relation Of House Construction and Kitchen Cleanness Eith Mouse Existence At The House Of Majapahit Village Citizen Kalierang Bumiayu Brebes]. Basically, the house has important role for human as their living place in order to fulfill their basic necessary and it is a citizen health determiner. The kind of this research is observational cross sectional approach. The method used is observation and interview directly on the respondent. Data analysis using table analysis, that is analyzed descriptively. As the result, it is known that from 86 houses, there are 52 houses (60.5\%) with clean kitchen, 34 houses (39.5\%) with dirty kitchen, 38 houses (44.2\%) with house construction which is closed of mouse, and 48 houses (33.7\%) with house construction which is not closed of mouse. The conclusion of this research is based on statistic test by using Chi-Square test, it is resulted sig score in the amount of 0.00 so sig<0.005 means that there is relation between house construction and kitchen cleanness with mouse existence. Suggestion should always clean the kitchen from leftover food / food and other scattered waste, construction of a house that has not been tightly mice to make a tight house construction rats.
\end{abstract}

Keyword: Kitchen cleanness, House construction, Mouse

1) Email: deviwidyaarianti@yahoo.com

2) Email: djamaluddin@gmail.com

3) Email: budut17@yahoo.co.id 


\section{Pendahuluan}

Pembangunan kesehatan menuju Indonesia Sehat 2025 adalah meningkatnya kesadaran, kemauan dan kemampuan hidup sehat bagi setiap orang agar meningkatkan derajat kesehatan masyarakat yang setinggi-tingginya dapat terwujud, melalui terciptanya masyarakat, Bangsa dan Negara Indonesia yang ditandai oleh penduduknya yang hidup dengan perilaku dan dalam lingkungan yang sehat, memiliki kemampuan untuk menjangkau pelayanan kesehatan yang bermutu secara adil dan merata, serta memiliki derajat kesehatan yang setinggitingginya di seluruh wilayah Republik Indonesia.

Masyarakat merupakan salah satu unsur utama dalam berdirinya suatu Negara. Negara yang makmur merupakan tanda bahwa Negara tersebut memiliki masyarakat yang juga makmur. Kemakmuran ini didukung adanya faktor. Salah satunya adalah kesehatan lingkungan. Kesehatan lingkungan merupakan keadaan lingkungan yang sehingga manusia membutuhkan tempat tinggal yaitu rumah. Rumah merupakan struktruk fisik tempat manusia berlindung beserta struktur lingkungan, dari struktur tersebut termasuk juga semua fasilitas dan pelayanan, perlengkapan yang berguna untuk kesehatan jasmani rohani dan keadaan sosial. Sesuai perkembangan jaman, tempat tinggal mengalami banyak perubahan sampai pada abad yang modern ini manusia sudah membangun rumah bertingkat dan di lengkapi dengan peralatan yang serba modern. Rumah dapat berfungsi sebagai tempat untuk menikmati kehidupan yang aman, nyaman, tempat untuk beristirahat, tempat berkumpulnya keluarga dan tempat untuk menjaga kesehatan. Rumah pada umumnya terdiri dari ruang tidur, ruang keluarga, ruang tamu, kamar mandi dan dapur.

Dapur merupakan tempat yang digunakan untuk memasak, sehingga di dalam dapur umumnya terdapat tempat-tempat peralatan untuk mengolah bahan makanan, menyimpan bahan makanan dan menyajikan makanan untuk keluarga. Dapur harus selalu dijaga kebersihanya karena dapur yang bersih akan menghasilkan makanan yang bersih dan terbebas dari tikus dan binatang pengganggu lainnya, dengan demikian kesehatan keluarga dapat dijaga melalui makanan yang sehat. Tempat sampah yang berada di dapur sering kurang diperhatikan oleh pemiliknya, sehingga dapat mengundang vektor dan binatang pengganggu seperti tikus.

Keberadaan tikus dapat mengganggu kenyamanan penghuni rumah, aktivitas menjadi terganggu, pekerjaan menjadi tidak selesai, merusak barang dan/ atau perabotan rumah, ada kemungkinan makanan dimakan tikus, makanan sisa tikus dimakan oleh manusia, sehingga dapat menyebabkan manusia menjadi sakit. Penyakit mendukung keseimbangan ekologi antara lingkungan dan manusia, sehingga mampu meningkatkan kesejahteraan, kesehatan dan kualitas hidup manusia (Soedarto, 2013). Kondisi lingkungan meliputi semua faktor-faktor eksternal yang berada di lingkungan sekitar manusia, yaitu: faktor fisik, kimia, biologi dan faktor lainnya. Kesehatan lingkungan memepelajari upaya-upaya menetapkan dan mengendalikan faktor-faktor lingkungan yang berpotensi menimbulkan dampak pada kesehatan. Faktor-faktor tersebut tidak termasuk sifat-sifat atau kebiasaan hidup yang dapat terkait dengan lingkungan, misalnya: lingkungan sosial, kultural serta genetik (Soedarto, 2013, h. 4-5).

Kebutuhan dasar manusia yang sangat berpengaruh dalam pembentukan kepribadian bangsa dibutuhkan sebuah tempat tinggal yang aman, nyaman, sebagai tempat berlindung dari bebagai ancaman yang datangnya dari luar

yang ditularkan oleh tikus, antara lain: Leptospirosis, pes, salmonella enterica seruvar typhimurin, rate bite fever (RBF), hantar virus pulmonary syndrome (HPS). Penyakit tersebut dapat ditularkan oleh tikus kepada manusia secara langsung oleh ludah, urin, maupun fesesnya dan atau melalui gigitan ektoparasitnya. (Departemen Kesehatan, 2002).

Manusia selalu mengupayakan agar tikus di rumah tidak ada, oleh karena itu manusia melakukan berbagai macam pengendalian, cara pengendalian yang sering dilakukan ada dua, yaitu: cara kimia dan mekanik. Pengendalian secara kimia dapat dilakukan dengan membunuh tikus menggunakan racun tikus dan bahan kimia lainnya, sedangkan secara mekanik dapat dilakukan dengan memperhatikan kebersihan lingkungan dapur dari bahan sisa makanan yang tercecer, menghilangkan tempat atau barang yang berpotensi menjadi sarang tikus dan memperhatikan konstruksi rumah agar rapat tikus (Rat Proofing). Mengingat bahwa bagian rumah yang sering terlihat kotor dan banyak terdapat sisa makanan maupun bahan makanan yang tercecer, sehingga konstruksi rumah dapat berpotensi adanya tikus masuk rumah dan dapur sangat potensial peranannya kaitan dengan kehadiran tikus.

Hasil survei pendahuluan ke rumah penduduk yang peneliti lakukan pada 11 Oktober 2017, didapatkan hasil bahwa terdapat tiga faktor yang berpotensi adanya tikus masuk ke dalam rumah penduduk, faktor pertama adalah kondisi rumah di Dusun Majapahit Kelurahan Kalierang Kecamatan Bumiayu Kabupaten Brebes terutama letak rumah yang berdekatan dengan hamparan sungai dan pesawahan. Faktor kedua adalah konstruksi rumah, misalnya: pintu, ventilasi, 
jendela, langit-langit yang tidak rapat tikus sehingga mempermudah masuknya tikus ke dalam rumah. Faktor ketiga adalah perilaku penghuni rumah dalam membersihkan dapur masih kurang memperhatikan kebersihan seperti: perilaku membersihkan dapur, menata tumpukantumpukan barang, membersihkan sisa-sisa makanan maupun bahan makan yang tercecer di dapur dan juga perilaku membuang sampah.

Perilaku yang membuat kondisi lingkungan dapur menjadi buruk tersebut dapat menunjang perkembangbiakan tikus. Upaya pencegahan keberadaan tikus di dapur dilakukan dengan memperhatikan konstruksi rumah agar tikus tidak dapat masuk rumah dan membersihkan lingkungan dapur, ini adalah cara yang mudah, murah, dan memberikan hasil yang maksimal. Hal itu sejalan dengan penelitian yang dilakukan Vita Qori Nurul (2014) bahwa keadaan rumah dengan perilaku masyarakat tersebut sangat memungkinkan menjadi sarang untuk hewan yang menjadi persebaran penyakit yaitu tikus. Peneliti bermaksud melakukan penelitian dengan judul "Hubungan Kebersihan Dapur dan Konstruksi Rumah dengan Keberadaan Tikus di Rumah Warga Dusun Majapahit Kelurahan Kalierang Kecamatan Bumiayu Kabupaten Brebes Tahun 2018".

\section{Tujuan Penelitian}

Tujuan penelitian ini adalah untuk Mengetahui hubungan kebersihan dapur dan konstruksi rumah dengan keberadaan tikus di rumah warga Dusun Majapahit Kelurahan Kalierang Kecamatan Bumiayu Kabupaten Brebes.

\section{Metode Penelitian}

Jenis penelitian ini adalah observasional dengan pendekatan cross sectional. Metode yang digunakan yaitu observasi, wawancara secara langsung pada responden. Analisis data menggunakan analisis tabel yaitu dianalisis secara deskriptif. Pendekatan cross sectional adalah suatu penelitian non-eksperimental untuk mempelajari dinamika kolerasi antara faktor-faktor dengan efek, dengan cara pendekatan observasi atau pengumpulan data sekaligus pada suatu saat yang bersama (point time approach) artinya tiap subjek penellitian hanya diobservasi sekali saja dan mengukuran pada dilakuakan terhadap status karakter atau variabel subjek pada pemeriksaan. (Notoatmodjo, 2010).

\section{Hasil dan Pembahasan}

Data hasil penelitian di rumah warga dilakukan untuk menyelesaikan tugas akhir atau skripsi. Penelitian ini dilakukan di Dusun Majapahit tepatnya di RW. 05 dan RT. 07, 08 dan 09 Kelurahan Kalierang Kecamatan Bumiayu Kabupaten Brebes. Dusun Majapahit dengan luas wilayah 8 Ha merupakan wilayah RW. 05, dengan Jumlah penduduk 635 jiwa. Dusun majapahit sendiri berbatasan dengan dusun ataupun RW/ RT lain yaitu:

Sebelah Utara : Dusun Krajan II

Sebelah Selatan : Dusun Krajan I Desa Jatisawit

Sebelah Barat : Dusun Munggang

Sebalah Timur : Dusun Pagenjahan dan Sawahsawah

Melihat dari data umum di atas Dusun Majapahit Kelurahan Kalierang Kecamatan Bumiayu Kabupaten Brebes merupakan lokasi yang berpotensi adanya keberadaan tikus, karena lokasinya merupakan wilayah padat penghuni dan rumah yang tidak ada batas antar rumah, sehingga segala sesuatu yang berada di rumah salah satu warga dapat dengan cepat berpindah ke rumah warga yang lain, tidak terkecuali tikus dan penyakitnya. Kemudian lokasi yang bersebelahan dengan sawah maupun pekarangan akan juga dapat berpotensi untuk adanya keberadaan tikus di rumah warga Dusun Majapahit Kelurahan Kalierang Kecamatan Bumiayu Kabupaten Brebes dikarenakan pada saat sawah atau pekarangan tidak ada makanan, maka tikus akan berpindah masuk ke dalam rumah khususnya dapur untuk mencari makanan, oleh karena itu perlu dilakukan pengendalian tikus di dalam maupun di sekitar rumah yaitu dengan menciptakan suatu kondisi lingkungan yang tidak memungkinkan untuk kehidupan tikus.

Tabel 4.1 Jumlah Rumah Warga yang disurvei di Dusun Majapahit Kelurahan Kalierang Kecamatan Bumiayu Kabupaten Brebes

\begin{tabular}{ccrr}
\hline No. & Lokasi & $\begin{array}{r}\text { Jumlah } \\
\text { (Rumah) }\end{array}$ & \% \\
\hline 1. & RT 07/RW 05 & 33 & 38.37 \\
2. & RT 08/RW 05 & 34 & 39.53 \\
3. & RT 09/RW 05 & 19 & 22.09 \\
\hline \multicolumn{2}{l}{ Total } & 86 & 100.00 \\
\hline
\end{tabular}

Tabel 4.2 Kebersihan Dapur Rumah Warga Dusun Majapahit Kelurahan Kalierang Kecamatan Bumiayu Kabupaten Brebes

\begin{tabular}{ccrr}
\hline No. & $\begin{array}{c}\text { Kebersihan } \\
\text { Dapur }\end{array}$ & $\begin{array}{r}\text { Jumlah } \\
\text { (Rumah) }\end{array}$ & $\%$ \\
\hline 1. & Bersih & 52 & 60.5 \\
2. & Kotor & 34 & 39.5 \\
\hline \multicolumn{2}{c}{ Total } & 86 & 100.0 \\
\hline
\end{tabular}

Jumlah rumah yang telah disurvei sebanyak 86 unit rumah dari total rumah telah disurvei dapat diketahui pada tabel 4.2 kebersihan dapur, ada 52 unit rumah atau $60.5 \%$ yang keadaan dapurnya bersih dan keadaan dapur yang kotor ada 34 unit rumah atau 39.5\%. Data tersebut diketahui bahwa di Dusun Majapahit Kelurahan Kalierang Kecamatan Bumiayu Kabupaten Brebes, dikatakan keadaan dapur yang bersih di karenakan banyak ibu rumah tangga yang jarang menggunakan dapurnya untuk mengolah makanan, sedangkan 
keadaan dapur yang tidak bersih dilihat dari nilai estetikanya terlihat kumuh dan kotor, banyak pula barang-barang yang tidak terpakai yang di tempatkan di bagian dapur, sehingga kebersihan dapurnya tidak dapat terjaga dan terlihat tidak indah/ bersih.

Berdasarkan hasil penelitian ini dapat dinyatakan bahwa jumlah rumah yang keadaan dapurnya bersih lebih banyak dari pada jumlah rumah yang keadaan dapurnya tidak bersih. Oleh karena itu ada beberapa rumah warga di Dusun Majapahit Kelurahan Kalierang Kecamatan Bumiayu Kabupaten Brebes tidak sesuai dengan syarat kesehatan tempat tinggal atau rumah yaitu hunian atau rumah harus terbebas dari binatang penular penyakit, tidak ada tikus yang bersarang di dalamnya. (Kepmenkes RI Nomor: 829 Tahun 1999).

Tabel 4.3 Konstruksi Rumah Warga Dusun Majapahit Kelurahan Kalierang Kecamatan Bumiayu Kabupaten Brebes

\begin{tabular}{ccrc}
\hline No. & $\begin{array}{c}\text { Konstruksi } \\
\text { Rumah }\end{array}$ & $\begin{array}{r}\text { Jumlah } \\
\text { (Rumah) }\end{array}$ & \% \\
\hline 1. & Rapat Tikus & 38 & 44.2 \\
2. & Tidak Rapat & 48 & 55.8 \\
& Tikus & & \\
\hline \multicolumn{2}{c}{ Total } & 86 & 100.0 \\
\hline
\end{tabular}

Hasil penelitian yang dilakukan, dan dapat dilihat pada tebel 4.3 konstruksi rumah di Dusun Majapahit Kelurahan Kalierang Kecamatan Bumiayu kabupaten Brebes terdapat 38 unit rumah atau $44.2 \%$ yang konstruksi rumahnya tidak ada celah untuk tikus masuk ke dalam rumah atau rapat tikus, sedangkan ada 48 unit rumah atau $55.8 \%$ konstruksi rumahnya tidak rapat tikus atau terdapat ruang yang dapat menyebabkan tikus masuk ke dalam rumah.

Dari penelitian yang telah dilakukan maka dapat disimpulkan bahwa rumah yang konstruksinya rapat tikus, hal tersebut di karenakan adanya ventilasi yang sudah dipasang kawat kassa, langitlangit rumah tidak bolong dan berwarna terang, pintu dapur yang tidak keropos atau tidak adanya ruang untuk tikus dapat masuk, dan saluran pembuangan yang tertutup atau rapat tikus. Konstruksi rumah yang tidak rapat tikus ini dapat dikarenakan ventilasi yang tidak dipasang kawat kassa, pintu dapur atau pintu lain yang keropos, saluran pembuangan yang tidak rapat tikus, dan rumah tidak terdapat langit-langit atau terdapat langit-langit, tetapi banyak yang rusak, sehingga tikus dapat masuk melalui ruang-ruang tersebut.

Tabel 4.4 Keberadaan Tikus di Rumah Warga Dusun Majapahit Kelurahan Kalierang Kecamatan Bumiayu Kabupaten Brebes

\begin{tabular}{ccrr}
\hline No. & $\begin{array}{c}\text { Keberadaan } \\
\text { Tikus }\end{array}$ & $\begin{array}{r}\text { Jumlah } \\
\text { (Rumah) }\end{array}$ & $\%$ \\
\hline 1. & Ada & 57 & 66.3 \\
2. & Tidak Ada & 29 & 33.7 \\
\hline
\end{tabular}

\begin{tabular}{cccc}
\hline Total & \multicolumn{2}{c}{86} & 100.0 \\
\hline Keberadaan & tikus & dapat & mengganggu
\end{tabular}
kelangsungan hidup manusia antara lain: tikus yang masuk kedalam rumah dapat merusak barang-barang yang ada di rumah, makanan tercecer dimana-mana karena dimakan dan dibawa oleh tikus, menimbulkan bau yang tidak sedap karena terdapat kotoran maupun kencing tikus, dan menjadikan rumah menjadi kotor dan tidak sehat, sehingga dapat menimbulkan penyakit dan adanya kerugian ekonomi akibat tikus yang masuk dalam rumah.

Hasil penelitian yang dilakukan dapat diketahui pada tabel 4.4 bahwa rumah yang terdapat adanya keberadaan tikus yang terlihat sebanyak 57 unit rumah atau $66.3 \%$ dan rumah yang tidak adanya keberadaan tikus yang terlihat sebanyak 29 unit rumah atau $33.7 \%$. Hal tersebut dapat disimpulkan bahwa keberadaan tikus di Dusun Majapahit Kelurahan Kalierang Kecamatan Bumiayu Kabupaten Brebes masih banyak terdapat adanya tikus yang masuk ke rumah. Hal ini dapat dilihat dari jumlah keberadaan tikus sebanyak 57 unit rumah atau $66.3 \%$ dari seluruh jumlah rumah yang disurvei sebanyak 86 unit rumah yang rumahnya masih terdapat adanya keberadaan tikus.

Berdasarkan data di atas secara umum dapat diketahui bahwa, kondisi rumah warga dalam kondisi yang tidak sehat sehingga mempengaruhi keberadaan tikus untuk ada di dalam rumah bahkan bersarang dan mencari makanan di dalam rumah serta dapat mempengaruhi kesehatan penghuni rumah tersebut. Menurut Kepmenkes RI Nomor: 829/Menkes/SKVII/1999, persyaratan kesehatan tempat tinggal atau rumah salah satunyanya adalah hunian harus terbebas dari binatang pengganggu yang dapat menularkan penyakit, tidak ada tikus yang bersarang di dalamnya.

Tabel 4.5 Frekuensi Pembersihan Dapur Rumah Warga Dusun Majapahit Kelurahan Kalierang Kecamatan Bumiayu Kabupaten Brebes

\begin{tabular}{ccrr}
\hline No. & $\begin{array}{c}\text { Frekuensi } \\
\text { Pembersihan } \\
\text { Dapur } \\
\text { (perhari) }\end{array}$ & $\begin{array}{c}\text { Jumlah } \\
\text { (Rumah) }\end{array}$ & $\%$ \\
\hline 1. & 1 & 50 & 58.1 \\
2. & 2 & 30 & 34.9 \\
3. & 3 & 5 & 5.8 \\
4. & $<3$ & 1 & 1.2 \\
\hline \multicolumn{4}{r}{ Total } \\
\multicolumn{2}{c}{ Berdasarkan hasil penelitian pada tabel 4.5 }
\end{tabular}
di Dusun Majapahit Kelurahan Kalierang Kecamatan Bumiayu Kabupaten Brebes, tepatnya di RW. 05, RT. 07, 08, 09 terhadap 86 unit rumah, ada 50 unit rumah atau $58.1 \%$ yang pembersihan dapurnya dilakukan 1 kali dalam sehari, 30 unit rumah atau $34.9 \%$ melakukan pembersihan dapurnya dilakukan 2 kali dalam sehari, 5 unit 
rumah atau $5.8 \%$ melakukan pembersihan dapurnya dilakukan 3 kali dalam sehari dan hanya ada 1 unit rumah atau $1.2 \%$ yang melakukan pembersihan dapur sebanyak 4 kali dalam sehari.

Berdasarkan data tersebut dapat disimpulkan bahwa dari total rumah yang di teliti sebanyak 86 unit rumah, frekuensi pembersihan dapur yang paling banyak di lakukan adalah 1 kali dalam sehari ada 50 unit rumah atau $58.1 \%$ dan hanya terdapat 1 unit rumah yang pembersihan dapurnya dilakukan 4 kali dalam sehari.

Tabel 4.6 Cara Membersihkan Dapur di Rumah Warga Dusun Majapahit Kelurahan Kalierang Kecamatan Bumiayu Kabupaten Brebes

\begin{tabular}{ccrr}
\hline No. & $\begin{array}{c}\text { Cara } \\
\text { Membersih- } \\
\text { kan Dapur }\end{array}$ & $\begin{array}{r}\text { Jumlah } \\
\text { (Rumah) }\end{array}$ & $\%$ \\
\hline 1. & Benar & 52 & 60.5 \\
2. & Salah & 34 & 39.5 \\
\hline \multicolumn{2}{c}{ Total } & 86 & 100.0 \\
\hline \multicolumn{2}{l}{ Hasil penelitian yang dilakukan di Dusun }
\end{tabular}

Majapahit Kelurahan Kalierang Kecamatan Bumiayu Kabupaten Brebes dapat dilihat pada tebel 4.6, bahwa ada 52 unit rumah atau $60.5 \%$ yang benar dan ada 34 unit rumah atau $39.5 \%$ yang salah dalam membersihkan dapur, adapun cara membersihkan dapur yang benar yaitu dengan menyapu sebelum dan sesudah melakukan aktivitas di dapur, mengepel dengan cara siapkan dua ember ember, ember pertama diisi dengan air biasa, ember kedua diisi dengan air yang sudah diisi dengan desinfektan, masukan kain pelpada ember berisi air lalu diperas setelah itu masukan kain pembersih lantai ke dalam air yang sudah berisi desinfektan kemudian diusapkan pada lantai, setelah itu bilas kembali dengan air biasa.

Tabel 4.7 Bahan Pembersih Dapur di Rumah Warga Dusun Majapahit Kelurahan Kalierang Kecamatan Bumiayu Kabupaten Brebes

\begin{tabular}{ccrc}
\hline No. & $\begin{array}{c}\text { Bahan } \\
\text { Pembersih }\end{array}$ & $\begin{array}{r}\text { Jumlah } \\
\text { (Rumah) }\end{array}$ & \% \\
\hline 1. & Mengunakan & 76 & 88.4 \\
2. & $\begin{array}{c}\text { Tidak } \\
\text { Menggunakan }\end{array}$ & 10 & 11.6 \\
\hline \multicolumn{2}{c}{ Total } & 86 & 100.0 \\
\hline
\end{tabular}

Hasil pemelitian yang dilakukan dapat diketahui pada tabel 7, di Dusun Majapahit Kelurahan Kalierang Kecamatan Bumiayu Kabeupaten Brebes bahwa terdapat 67 unit rumah atau $88.4 \%$ yang masuk dalam kategori menggunakan bahan pembersih yang membuat ruangan tersebut menjadi bersih tidak ada kotoran, dan rumah yang masuk dalam kategori tidak menggunakan bahan pembersih ada sekitar 10 unit rumah atau $11.6 \%$. Adapun pembersih yang digunakan setiap rumah adalah soklin lantai.

Tabel 4.8 Keberadaan Sisa makanan/ Bahan Makanan di Dapur Warga Dusun Majapahit Kelurahan Kalierang
Kecamatan Bumiayu Kabupaten Brebes

\begin{tabular}{|c|c|c|c|}
\hline No. & $\begin{array}{c}\text { Keberadaan } \\
\text { sisa makanan/ } \\
\text { bahan } \\
\text { makanan }\end{array}$ & $\begin{array}{r}\text { Jumlah } \\
\text { (Rumah) }\end{array}$ & $\%$ \\
\hline 1. & Ada & 34 & 39.5 \\
\hline 2. & Tidak ada & 52 & 60.5 \\
\hline \multicolumn{2}{|r|}{ Total } & 86 & 100.0 \\
\hline
\end{tabular}

dilakukan diketahui bahwa pada tabel 4.8 , bahwa terdapat sisa makanan/ bahan makanan yang tercecer di dapur ada 34 rumah atau $39.5 \%$ dan ada 52 rumah atau $60.5 \%$ yang tidak ada makanan/bahan yang tercecer. Hal tersebut dikarenakan penghuni rumah yang kurang memperhatikan kebersihan dapurnya pada makanan/ bahan yang tercecer.

Tabel 4.9 Hubungan Kebersihan Dapur dengan Keberadaan Tikus di Rumah Warga Dusun Majapahit Kelurahan Kalierang Kecamatan Bumiayu Kabupaten Brebes

\begin{tabular}{crrr}
\multirow{2}{*}{$\begin{array}{c}\text { Kebersihan } \\
\text { Dapur }\end{array}$} & \multicolumn{2}{c}{ Keberadaan Tikus } & \\
\cline { 2 - 3 } & Ada & Tidak Ada & Total \\
\hline \multirow{2}{*}{ Bersih } & 24 & 28 & 52 \\
& $46.2 \%$ & $53.8 \%$ & $100.0 \%$ \\
\multirow{2}{*}{ Kotor } & 33 & 1 & 34 \\
\multirow{2}{*}{ Total } & $97.1 \%$ & $2.9 \%$ & $100.0 \%$ \\
\hline
\end{tabular}

Berdasarkan hasil survei yang dilakukan peneliti diperoleh hasil, terdapat 52 unit rumah yang keadaan dapurnya bersih dan 34 unit rumah yang keadaan dapurnya kotor dari total rumah yang telah disurvei sebanyak 86 unit rumah atau $100.0 \%$, dari total 52 unit rumah yang keadaan dapurnya bersih terdapat 24 unit rumah atau 46.2 $\%$ yang dapurnya terdapat keberadaan tikus dan 28 unit rumah atau $53.8 \%$ yang dapurnya tidak terdapat keberadaan tikus. Total rumah yang dapurnya dalam keadaan kotor ada 34 unit rumah atau $100.0 \%$ diketahui bahwa terdapat keberadaan tikus dengan jumlah rumah 33 unit rumah atau $97.1 \%$ dan terdapat 1 unit rumah atau $2.9 \%$ yang dapurnya diketahui tidak terdapat keberadaan tikus.

Kesimpulan dari total rumah yang telah disurvei yaitu sebanyak 86 unit rumah atau 100.0 $\%$ diketahui bahwa dari total kebersihan dapur yang bersih maupun tidak bersih ada 57 unit rumah atau $66.3 \%$ yang terdapat adanya keberadaan tikus, dan ada 29 unit rumah atau $33.7 \%$ yang tidak terdapat adanya keberadaan tikus. Data di atas secara umum dapat dikatakan bahwa, kondisi dapur warga di Dusun Majapahit Kelurahan Kalierang Kecamatan Bumiayu Kabupaten Brebes masih banyak adanya keberadaan tikus dikarenakan masih banyak tikus yang masuk ke dalam dapur ingin mencari makanan dan biasanya 
tikus lebih suka di tempat yang lembab, gelap, lingkungan yang kotor dan juga tempat yang banyak bahan makanannya seperti di dapur.

Tabel 4.10 Chi-Square Test Hubungan Kebersihan Dapur dengan Keberadaan Tikus di Rumah Warga Dusun Majapahit Keliurahan Kalierang Kecamatan Bumiayu Kabupaten Brebes

\begin{tabular}{|c|c|c|c|c|c|}
\hline & Value & $\mathrm{df}$ & $\begin{array}{c}\text { Asymp. } \\
\text { Sig. (2- } \\
\text { sided) }\end{array}$ & $\begin{array}{c}\text { Exact } \\
\text { Sig. } \\
(2- \\
\text { sided })\end{array}$ & $\begin{array}{c}\text { Exact } \\
\text { Sig. } \\
(1- \\
\text { sided })\end{array}$ \\
\hline $\begin{array}{l}\text { Pearson } \\
\text { Chi-Square }\end{array}$ & $23.836^{\mathrm{a}}$ & 1 & .000 & & \\
\hline $\begin{array}{l}\text { Continuity } \\
\text { Correction }^{\mathrm{b}}\end{array}$ & 21.612 & 1 & .000 & & \\
\hline $\begin{array}{l}\text { Likelihood } \\
\text { Ratio }\end{array}$ & 29.134 & 1 & .000 & & \\
\hline $\begin{array}{l}\text { Fisher's } \\
\text { Exact Test }\end{array}$ & & & & .000 & .000 \\
\hline $\begin{array}{l}\text { Linear-by- } \\
\text { Linear }\end{array}$ & 23.559 & 1 & .000 & & \\
\hline $\begin{array}{l}\text { Association } \\
\mathrm{N} \text { of Valid } \\
\text { Cases }\end{array}$ & 86 & & & & \\
\hline
\end{tabular}

Kebersihan Dapur dengan Keberadaan Tikus bahwa person Chi-Square nilai sig. (2-sided) yaitu $0.00<0.05$ sehingga dapat di katakan ada hubungan dapur yang kotor dengan keberadaan tikus di rumah warga Dusun Majapahit Kelurahan Kalierang Kecamatan Bumiayu Kabupaten Brebes. Dapur yang kotor dapat mengundang keberadaan tikus karena di dalam dapur tersebut terdapat banyak sisa makanan yang tidak di bersihkan, keadaan dapur di sana terlihat kumuh dan banyak barang-barang yang tidak terpakaipun tidak di bersihkan sehingga dapat di jadikan sarang bagi tikus dan tikus tersebut suka pada tempat yang kumuh, sehingga keadaan tersebut dapat mengundang adanya tikus masuk ke dalam dapur.

Berdasarkan hasil penelitian dengan diperoleh hasil, terdapat 38 unit rumah yang konstruksi rumahnya rapat tikus dan 48 unit rumah yang konstruksi rumahnya tidak rapat tikus dari total rumah yang telah disurvei sebanyak 86 unit rumah atau $100.0 \%$, total rumah dengan konstruksi rumahnya rapat tikus ada 38 unit rumah, terdapat 10 unit rumah atau $26.3 \%$ dengan konstruksi rumahnya terdapat keberadaan tikus dan 28 unit rumah atau $73.7 \%$ dengan konstrkusi rumahnya yang rapat tikus diketahui tidak terdapat keberadaan tikus. Total rumah dengan konstruksi rumah tidak rapat tikus ada 48 unit rumah atau $100.0 \%$ diketahui bahwa terdapat keberadaan tikus dengan jumlah rumah 47 unit rumah atau $97.9 \%$ dan terdapat 1 unit rumah atau $2.1 \%$ dengan konstruksi rumah yang rapat tikus diketahui tidak terdapat keberadaan tikus.

Kesimpulan dari total rumah yang telah disurvei yaitu sebanyak 86 unit rumah atau 100.0 $\%$ dapat diketahui bahwa dari total konstruksi rumah yang rapat tikus maupun tidak rapat tikus ada 57 unit rumah atau $66.3 \%$ yang terdapat adanya keberadaan tikus, dan ada 29 unit rumah atau $33.7 \%$ yang tidak terdapat adanya keberadaan tikus.

Berdasarkan data di atas secara umum dapat dikatakan bahwa, konstruksi rumah warga di Dusun Majapahit Kelurahan Kalierang Kecamatan Bumiayu Kabupaten Brebes, masih banyak adanya keberadaan tikus di rumah dikarenakan konstruksi rumah yang tidak rapat tikus sehingga tikus mudah untuk masuk ke dalam rumah.

Tabel 4.12 Chi-Square Test Hubungan Konstruksi Rumah dengan Keberadaan Tikus di Rumah Warga Dusun Majapahit Kelurahan Kalierang Kecamatan Bumiayu Kabupaten Brebes

\begin{tabular}{|c|c|c|c|c|c|}
\hline & \multirow[b]{2}{*}{ Value } & \multicolumn{4}{|c|}{ Exact } \\
\hline & & $\mathrm{df}$ & $\begin{array}{c}\text { Asymp. } \\
\text { Sig. (2- } \\
\text { sided) }\end{array}$ & $\begin{array}{c}\text { Sig. } \\
(2- \\
\text { sided) }\end{array}$ & $\begin{array}{l}\text { Exact } \\
\text { Sig. (1- } \\
\text { sided) }\end{array}$ \\
\hline $\begin{array}{l}\text { Pearson Chi- } \\
\text { Square }\end{array}$ & $48.650^{\mathrm{a}}$ & 1 & .000 & & \\
\hline Continuity & 45.500 & 1 & .000 & & \\
\hline Correction $^{\mathrm{b}}$ & & & & & \\
\hline $\begin{array}{l}\text { Likelihood } \\
\text { Ratio }\end{array}$ & 56.414 & 1 & .000 & & \\
\hline
\end{tabular}

Fisher's Exact

.000

.000

Test

Linear-by- $\quad 48.085 \quad 1 \quad .000$

Linear

Association

$\mathrm{N}$ of Valid $\quad 86$

Cases

Data hasil uji Chi-Square Test, Hubungan Konstruksi Rumah dengan Keberadaan Tikus bahwa Person Chi-Square nilai sig. (2-sided) yaitu $0.00<0.05$ sehingga dapat dikatakan ada hubungan konstruksi rumah yang tidak rapat tikus dengan keberadaan tikus di rumah warga Dusun Majapahit 
Kelurahan Kalierang Kecamatan Bumiayu Kabupaten Brebes.

Konstruksi rumah yang tidak rapat tikus seperti tidak adanya kawat kassa pada ventilasi, rumah yang tidak ada langit-langitnya, pintu dapur dan jendela rumah yang dibiarkan membuka dan keropos sehingga tikus dapat dengan mudah masuk ke dalam rumah, dan saluran pembuangan yang tidak ditutup.

Kondisi tersebut di sebabkan karena tikus lebih suka pada tempat yang kotor, tempat gelap, banyak barang-barang yang tertumpuk yang tidak terpakai, tempat yang banyak bahan makanan dan konstruksi rumah yang tidak rapat tikus serta lingkungan yang buruk. Selain itu juga tikus sering membawa bibit penyakit zoonosis antara lain: (penyakit bersumber binatang) yaitu pes, murine thypus, scrub thypus, leptospirosis, dan juga penyaki-penyakit yang lain. (Departemen Kesehatan, 2002)

Oleh karena itu dapat dilakukan perbaikan sanitasi dan pengendalian tikus baik di dalam maupun di luar rumah secara berkala agar tingkat populasi tikus dapat dikendalikan pada tingkat yang rendah.

\section{Kesimpulan dan Saran Simpulan}

Kesimpulan dari penelitian ini yaitu dengan hasil pengamatan dan wawancara yang dilakukan oleh peneliti dengan menggunakan ceklist dan kuesioner adalah sebagai berikut:

86 unit rumah total keseluruhan diketahui ada 52 unit rumah $(60.5 \%)$ keadaan dapurnya bersih dan 34 unit rumah $(39.5 \%)$ dengan keadaan dapurnya tidak bersih. 38 unit rumah (44.2\%) konstruksi rumahnya rapat tikus dan 48 unit rumah (55.8\%) dengan kontruksi rumahnya tidak rapat tikus. 57 unit rumah $(66.3 \%)$ terdapat adanya keberadaan tikus dan 29 unit rumah $(33.7 \%)$ yang rumahnya tidak terdapat keberadaan tikus. Hasil keberadaan tikus di dapur yang bersih terdapat adanya keberadaan tikus, ada 24 unit rumah $(46.2 \%)$, dan yang tidak adanya keberadaan tikus ada 28 unit rumah $(53.8 \%)$. Hasil keberadaan tikus di dapur yang tidak bersih terdapat adanya keberadaan tikus, ada 33 unit rumah (97.1\%), dan yang tidak adanya keberadaan tikus di dapur, ada 1 unit rumah (2.9\%). Dari hasil uji Test Chi-Square, Hubungan Kebersihan Dapur dengan Keberadaan Tikus yaitu $0.00<0.05$ sehingga dapat dikatakan ada hubungan dapur yang kotor dengan keberadaan tikus di rumah warga Dusun Majapahit Kelurahan Kalierang Kecamatan Bumiayu Kabupaten Brebes. Hasil keberadaan tikus dilihat dari konstruksi rumah yang rapat tikus, ada 10 unit rumah $(26.3 \%)$, dan tidak adanya keberadaan tikus, 28 unit rumah $(73.7 \%)$. Hasil keberadaan tikus dilihat dari konstruksi rumah yang tidak rapat tikus, ada 47 rumah (97.9\%), 1 rumah $(2.1 \%)$ yang terdapat adanya keberadaan tikus dilihat dari konstrusksi rumah yang tidak rapat tikus. Dari hasil uji Test Chi-Square, Hubungan Konstruksi Rumah dengan Keberadaan Tikus yaitu $0.00<0.05$ sehingga dapat dikatakan ada hubungan konstruksi rumah tidak rapat tikus dengan keberadaan tikus di rumah warga Dusun Majapahit Kelurahan Kalierang Kecamatan Bumiayu Kabupaten Brebes.

\section{Saran}

a. Sebaiknya selalu membersihkan rumah dan dapur dari sisa makanan atau bahan makanan yang tercecer.

b. Sebaiknya rumah konstruksinya masih belum rapat tikus untuk dibuat rapat tikus.

\section{Daftar Pustaka}

Arni Dyan Mayasari. 2013. "Hubungan Antara Sanitasi Rumah Warga dengan Jumlah Tikus dan Kepadatan Pinjal di Desa Selo Kecamatan Selo Boyolali: Skripsi, Universitas Muhamadiyah Surakarta”. http://eprints.ums.ac.id/26278/1/HALAMAN _DEPAN.pdf. Diakses Rabu, 25 Oktober 2017. Pukul 13.00 WIB.

Arif Fadillah. 2011. “Mengenal Bagian Rumah”. http://www.ilmusipil.com/mengenal-bagianruang-rumah. Diakses. 3 Januari 2018. Pukul 16.49 WIB.

Aziz Awaludin. 2011. "Studi tentang Jumlah dan Jenis Tikus Serta Pinjal dan Pengendaliannya di Perumahan Griya Bukateja Baru Desa Kedungjati Kecamatan Bukateja Kabupaten Purbalingga": KTI, Poltekkes Kemenkes Semarang.

Diandra Pandu Saginatari. 2011. Dapur Bersih dan Dapur Kotor Prmisah Zona Depan dan Zona Belakang di Ruang Domestik: Skripsi Universitas Indonesia. http://lib.ui.ac.id/file?file=digital/20211138S140-Dapur\%20bersih.pdf. Diakses Senin, 23 Oktober 2017. Pukul 16.30 WIB.

Entjang indan. 2000. "Ilmu Kesehatan Prilaku tentang Persyaratan Dapur Sehat”. Bandung.

Adang Iskandar. dkk. 1985. Pedoman Bidang Studi Pemberantasan Serangga dan Binatang Pengganggu 1985. Departemen Kesehatan RI, Jakarta.

http.wikipedia.org, “Dapur”, Diakses Rabu, 25 Oktober 2017, Pukul 19.00 WIB. 
https://www.scribd.com/document/326124674/Pe ngertian-Rumah-Sehat-Menurut-WHO. Diakses. Selasa, 2 Desember 2018. Pukul 01.05 WIB

http://www.academia.edu/20213549/Form_Inspek si_Sanitasi_Rumah_Sehat. Diakses. Kamis, 4 Desember 2018. Pukul 07.00 WIB.

Indonesia. Dep. Kes. RI. Dit. Jen. PP dan PL, 2002. "Pedoman Pengendalian Tikus Khusus Di Rumah Sakit”. Cetakan 2002. Jakarta.

Indonesia, Presiden Republik Indonesia, 2011, Undang-undang Republik Indonesia Nomer 1 Tahun 2011 tentang Perumahan dan Kawasan Permukiman. Jakarta.

Kepmenkes. No. 829. Tahun 1999. "Persyaratan Rumah Sehat". https://www.scribd.com/document/274953059 /Kepmenkes-RI-No-829-Tahun-1999Persyaratan-Kesehatan-Perumahan Diakses. Rabu, 3 Januarai 2018. Pukul 11.20 WIB.

Notoatmodjo. 2002. "Pengertian Cross Sectional". https:// www.scribd.com/doc/89623155/CrossSectional1. Diakses Rabu, 3 Januari 2018. Pukul 12.30 WIB.

Resi Aneka Saputra. 2015. "Identifikasi Kepadatan dan Ektoparasit Tikus di Daerah Perimeter, Buffer dan Permukiman terdekat KKP Kelas II Cilacap”. KTI. Poltekkes Kemenkes Semarang.
Soedarto. 2013. Lingkungan dan Kesehatan (Environment and Health). https://www.researchgate.net/publication/257 653963_Environment_and_Health_-

Lingkungan_dan_Kesehatan. Diakses Selasa, 2 Januari 2018. Pukul 03.42 WIB.

Soedjajadi Keman. 2005. "Kesehatan Perumahan dan Lingkungan Permuiman”. Jurnal Kesehatan Lingkungan. Vol.2. No. 1. Juli. 2005:29-42.

Tri Cahyono. 2014. Pedoman Penelitian Proposal Penelitian dan Karya Tulis Ilmiah/Skripsi (Edisi Revisi Ketiga). Purwokerto: Kementrian Kesehatan Republik Indonesia Politeknik Kesehatan Kemnkes Semarang Jurusan Kesehatan Lingkungan Purwokerto.

Tri Cahyono. 2014. Pedoman Penelitian Proposal Penelitian dan Karya Tulis Ilmiah/Skripsi (Edisi Revisi Keempat). Purwokerto Kementrian Kesehatan Republik Indonesia Politeknik Kesehatan Kemnkes Semarang Jurusan Kesehatan Lingkungan Purwokerto.

Vita Qori Nurul Fadzilah. 2014. Hubungan Perilku Masyarakat tentang Kebersihan Lingkungan dengan Keberadaan Tikus di Desa Lecoh Kecamatan Selo Kabupaten Bayolali: Skripsi. Universitas Muhamadiyah Surakarta. http://eprints.ums.ac.id/31195/. Diakses. Kamis 12 Oktober 2017. Pukul 14.00 WIB. 